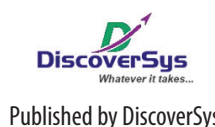

Published by DiscoverSys

\section{Exclusive breastfeeding: The role of midwives at pregnancy, childbirth and postpartum}

\author{
Ni Kadek Neza Dwiyanti, ${ }^{1 *}$ Komang Ayu Kartika Sari, ${ }^{2}$ \\ Dyah Pradnyaparamitha Duarsa ${ }^{2}$
}

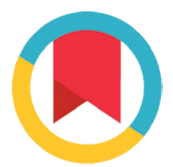

CrossMark

\title{
ABSTRACT
}

Background and purpose: The coverage of exclusive breastfeeding is reported to be low. The aim of this study was to explore the extent of the roles of midwives during pregnancy, childbirth and postpartum to increase exclusive breastfeeding.

Methods: This study applied a qualitative approach by in-depth interviews based on interview guidelines to explore the role of midwives in increasing exclusive breastfeeding during pregnancy, childbirth and postpartum. This study was conducted in the area of Kuta I Public Health Center (PHC), Badung District, Bali Province from October 2017 to July 2018. Interviews were conducted with 12 informants chosen purposively, namely three PHC midwives, two private practice midwives, one nutrition program manager, four mothers who managed to provide exclusive breastfeeding and two who did not. Data were analyzed with a thematic approach.

Results: This study shows that the roles of midwives are not optimal. The role that has been carried out during pregnancy is to provide information about breast care but not to practice breast care. During labor, the midwife facilitated the initiation of early breastfeeding except for mothers who experienced childbirth complications. During the postpartum period the midwife provides information about breastfeeding to working mothers and monitors exclusive breastfeeding at the integrated health services centers or in Indonesia called pos pelayanan terpadu (posyandu) until the infant reach the age of six months. Midwives provide information about breast care and how to overcome problems in breastfeeding, but do not facilitate the practice of both. All midwives do not conduct home visits for several reasons, such as distance to residents' homes, high burden of tasks and lack of human resources. Midwives also provide counselling at posyandu on maternal and child nutrition but do not focus on exclusive breastfeeding.

Conclusion: The roles of midwives in facilitating exclusive breastfeeding during pregnancy, childbirth and postpartum are still superficial and not in accordance with the guidelines for obstetric care. The roles of midwives need to be enhanced to increase exclusive breastfeeding.

Keywords: Role of midwives, exclusive breastfeeding, pregnancy, childbirth, postpartum

Cite This Article: Dwiyanti, N.K.N., Sari, K.A.K., Duarsa, D.P. 2019. Exclusive breastfeeding: The role of midwives at pregnancy, childbirth and postpartum. Public Health and Preventive Medicine Archive 7(2): 127-134. D0I:10.15562/phpma.v7i2.219

${ }^{1}$ The Bali Province Health Institute ${ }^{2}$ Department of Public Health and Preventive Medicine, Faculty of Medicine, Udayana University

*Correspondence to: Ni Kadek Neza Dwiyanti, The Bali Province Health Institute, nezhadwiyanthi@gmail.com

\section{INTRODUCTION}

Indonesian Government Regulation No. 33/2012 recommends that exclusive breastfeeding should be given to infants from birth to six months of age. ${ }^{1}$ Various studies have shown that breast milk has benefits for both mother and infant, such as stopping postpartum haemorrhage and increasing the infant's immunity so that it reduces the risk of premature death. ${ }^{2-6}$ Although exclusive breastfeeding has been known to have many benefits, the 2014 Indonesia Basic Health Research or called Riset Kesehatan Dasar (Riskesdas) shows that the coverage of exclusive breastfeeding in Indonesia remained low at $15.3 \%$. In the Province of Bali, the coverage of exclusive breastfeeding in 2015 was $72.8 \%$, far higher than the coverage of exclusive breastfeeding in Indonesia but remained unable to meet the national target of $80 \%$. Some districts in Bali that have exclusive breastfeeding coverage below the target are Badung at $70.29 \%$, Buleleng at $61.95 \%$ and Karangasem at $69.68 \%{ }^{7}$
Midwives have some important roles in efforts to increase coverage of exclusive breastfeeding, such as providing advocacy and promotion regarding exclusive breastfeeding and training to improve the quality of service. ${ }^{1}$ Prayogo's study ${ }^{4}$ shows that counselling from midwives is needed to improve the knowledge of pregnant and lactating women related to exclusive breastfeeding. Based on the guidelines in the Maternal and Child Health Book $(\mathrm{MCH})$ related to exclusive breastfeeding, promotion efforts to mothers should be carried out starting from pregnancy, during labor and the postpartum period. ${ }^{8}$ During pregnancy the midwife should provide counselling, pregnancy examinations and breast care. Immediately after delivery the midwife facilitates early breastfeeding initiation and during the postpartum midwife should make home visits, provide counselling on how to breastfeed properly, how to overcome problems during breastfeeding, teach mothers how to breastfeed, teach mothers 
about the position and attachment in breastfeeding, provide explanation to breastfeeding mothers about how to express, store and present breast milk. ${ }^{8}$

Studies on the role of midwives in efforts to increase exclusive breastfeeding at all three stages have not been published yet. Various studies related to the role of midwives also showed inconsistent results. Previous studies used more quantitative designs and examined more about midwives' knowledge and the effect of counselling or education by midwives on the success of exclusive breastfeeding. ${ }^{2-6}$ Another study conducted at PHC Sruwohrejo, Purworejo District found that the role of a good midwife had no effect on exclusive breastfeeding. ${ }^{9}$ A qualitative study conducted at Abiansemal PHC, Badung District focuses on providing counselling and information to pregnant women related to breast care, so that it has not yet thoroughly explored the role of midwives in efforts to increase exclusive breastfeeding at each stage of pregnancy, childbirth and postpartum. ${ }^{10}$

A preliminary study through informal interviews with exclusive breastfeeding program managers and midwives who worked at Kuta I PHC, Kuta Sub-District of Badung District indicated that probably not all of the midwife's roles recommended in the Midwifery Guidelines could be carried out due to various obstacles. This study aims to explore the extent of the roles of midwives during pregnancy, childbirth and postpartum in efforts to increase exclusive breastfeeding.

\section{METHODS}

This study used an explorative qualitative design to investigate the roles of midwives to increase exclusive breastfeeding from the time of pregnancy, childbirth and the postpartum period until the infant reaches six months old. This study was conducted at Kuta I PHC, Kuta Sub-district, Badung District, Bali Province in October 2017 to July 2018. Based on the profile of the Badung District Health Office in 2018, Kuta Sub-district has the smallest area but with the highest population density compared to other sub-districts in Badung. ${ }^{11}$ Kuta Sub-district is one of the national and international tourism destination areas in Badung District which has the highest minimum wage compared to other districts in Bali Province. The Kuta I PHC area is one of the regions that has the lowest exclusive breastfeeding coverage in Badung District, which is $60 \%$. Coverage of deliveries by trained health workers in the work area of Kuta I PHC was $87 \%$, while coverage of postpartum maternal services was $72 \%$. Those both services coverage is obtained only from private practice midwives and PHC but does not include services by private doctors and hospitals. ${ }^{11}$
This study applied in-depth interviews based on interview guidelines conducted by the researchers. Interviews were conducted with 12 informants who were selected purposively consisting of three midwives who served at Kuta I PHC, two private midwives in the work area of Kuta I PHC, one nutrition program manager, four mothers who had infants over six months old that managed to give exclusive breastfeeding to her infant during the first six months and two mothers who have infants aged over six months but were unable to provide exclusive breastfeeding. Information explored from the mothers were their experiences regarding breast care during antenatal care (ANC), early breastfeeding initiation and exclusive breastfeeding after delivery. Information explored from the midwives and nutrition program manager were their roles during antenatal care, childbirth and post natal period in order to increase exclusive breastfeeding among mothers. Interviews with PHC midwives and nutrition program manager were carried out at different times in a private room in Kuta I PHC, while interviews with private midwives were carried out at the practice location of each midwife. Interviews with mothers were carried out in each informant's house. The interview process was recorded with a recording device then the interview transcripts were made by listening to the recorded interviews repeatedly and combining them with the researcher's notes which taken during data collection.

Data were analyzed thematically starting with identifying the code from the interview transcript manually, followed by grouping the code and identifying themes that emerged. The data in this study were validated using source triangulation which aims to ensure the validity of data from several sources, namely stakeholders who play a role in exclusive breastfeeding programs and mothers who have infants older than 6 months. The results of the analysis in this study are presented in the form of narratives and are complemented with quotations from respondents' statements in their original form.

This study has been approved by The Ethics Committee of the Faculty of Medicine, Udayana University/Sanglah Hospital, Denpasar on April 5, 2018.

\section{RESULTS AND DISCUSSION}

\section{Characteristics of informants}

Table 1 shows that one midwife has the education level of Diploma II (DII) Midwifery, four DIII Midwifery and one nutritional DIV. It also shows that five informants are government employees and one is a non-permanent health staff. Three informants are midwives who worked at PHC, two are private midwives and one is a nutrition program 
manager at PHC. Informants in this study are aged between 32 to 49 years, with a length of work of 10 to 26 years.

Table 2 shows that the age of mothers of children under five is in the range of 23 to 43 years with the highest level of education is senior high school and the lowest is junior high school. One of the mothers worked at a private sector and the other five were housewives. Based on the status of exclusive breastfeeding, two mothers were not able to give exclusive breastfeeding to their children during the first six months and four mothers succeeded in giving exclusive breastfeeding. ANC sites of the mothers include private midwife, PHC and maternity clinics. The highest number of children is four and the lowest is one, with the youngest child aged eighteen months and the oldest at four years.

\section{The role of midwives in efforts to increase exclusive breastfeeding}

This study indicates that the role of midwives in increasing exclusive breastfeeding in general is not optimal. There are three main themes that emerged from this study, namely the role of midwives in preparing pregnant women for breastfeeding, the role of midwives in facilitating early breast feeding initiation in maternity and the role of midwives in efforts to maintain exclusive breastfeeding from the postpartum period until the infant reaches the age of six months old.

\section{The role of the midwife in preparing pregnant women for exclusive breastfeeding}

The results of interviews with mothers and midwives showed that midwives had provided information about breast care during ANC but did not train mothers directly to practice breast care and examinations. Midwives described that they usually only provide an explanation of how to conduct breast care when the pregnancy enters the third trimester and provide breast care to pregnant women who need it, for example, those who need particular nipple care. All mothers also said that they were only reminded to take care of the breast during pregnancy but were never directly trained by the midwife how to do this. All mothers are advised by midwives to find their own information about breast care in the MCH Book.

"... Well, when we examined them at the ANC we also saw the area emmm ... if the nipple is inverted, the patient can review the IEC (Information, Education, Communication pamphlet) on how to clean the nipple. Yes, it's starting from the ANC... we just give IEC for breast care..." (IN 04_midwife)

“... no ... when the woman is pregnant the midwife educates the woman on how to clean their nipples... right from this book ... until the mother gave birth the information is basically just that ... But sometimes in the posyandu it is also explained but only explained it is not practiced. "(IN 08_mother)

Table 1 Characteristics of midwives and nutrition program managers

\begin{tabular}{|c|c|c|c|c|c|}
\hline Code & Age (years) & Education & Occupation & Work status & Working years \\
\hline IN 01 & 49 & DIII Midwifery & PHC midwife & Government employee & 26 years \\
\hline IN 02 & 48 & DIII Midwifery & PHC midwife & Non-permanent staff & 12 years \\
\hline IN 03 & 32 & DIII Midwifery & PHC midwife & Government employee & 10 years \\
\hline IN 04 & 42 & DIII Midwifery & Private midwife & Government employee & 16 years \\
\hline IN 05 & 45 & DII Midwifery & Private midwife & Government employee & 23 years \\
\hline IN 06 & 38 & DIV Nutrition & Nutrition program manager & Government employee & 10 years \\
\hline
\end{tabular}

Table 2 Characteristics of the mother of under-five children

\begin{tabular}{|c|c|c|c|c|c|c|c|c|}
\hline Name & Age (years) & Last education & Occupation & $\begin{array}{c}\text { Exclusive } \\
\text { breast feeding }\end{array}$ & ANC site & $\begin{array}{l}\text { Marriage } \\
\text { status }\end{array}$ & $\begin{array}{l}\text { No of } \\
\text { children }\end{array}$ & $\begin{array}{c}\text { Age of youngest } \\
\text { child }\end{array}$ \\
\hline IN 07 & 43 & Senior High & Housewife & No & Midwives & Married & 1 & 18 months \\
\hline IN 08 & 37 & Senior High & Private employee & Yes & $\mathrm{PHC}$ & Married & 2 & 4 years \\
\hline IN 09 & 26 & Senior High & Housewife & Yes & Midwives & Married & 2 & 3 years \\
\hline IN 10 & 25 & Senior High & Housewife & Yes & $\mathrm{PHC}$ & Married & 2 & 2 years \\
\hline IN 11 & 34 & Senior High & Housewife & Yes & Midwives & Married & 4 & 1,5 years \\
\hline IN 12 & 23 & Senior High & Housewife & No & ANC & Married & 1 & 2,5 years \\
\hline
\end{tabular}


Interviews with all mothers showed that they never received counselling or information about exclusive breastfeeding when they came to posyandu during pregnancy. On the other hand, midwives stated that group education about exclusive breastfeeding for pregnant women at posyandu had been carried out together with program managers. This statement was supported by the nutrition program manager who stated that group education had been carried out jointly with the $\mathrm{MCH}$ program manager and several midwives.

"...Never. Only about pregnancy there, there is no counselling like that .. "(IN 10_mother)

"... um, breastfeeding group education is usually available for pregnant women, we are usually together with the program manager during posyandu" (IN 01_PHC midwife)

"For the education of the group, the nutrition program manager, $\mathrm{MCH}$ and several midwives... We regularly offer counselling at the posyandu or in the village ..." (IN 06_nutrition program manager)

This study indicates that midwives are limited to explaining how to treat breast care for pregnant women, but do not train them directly how to do breast care properly. The role of the midwife is not in accordance with the guidelines in the $\mathrm{MCH}$ handbook which states that midwives should provide counselling about the preparation of exclusive breastfeeding and conduct health examinations, pregnancy and breast care during pregnancy. ${ }^{8} \mathrm{~A}$ study by Whaisna, et $\mathrm{al}^{12}$ states that the success of antenatal breast care accelerated the secretion of colostrum in post-partum mothers in the Malang Hospital.

Several studies on breast care are more commonly found in the postpartum period..$^{13,14}$ Whereas there is no specific study regarding breast care during pregnancy and most studies concern about providing breastfeeding education in general. ${ }^{15}$ Some studies indicate the lack of information regarding exclusive breastfeeding for pregnant women by midwives. ${ }^{16,17}$

Our study also found that all mothers had never received information about exclusive breastfeeding even though midwives and program managers stated they had conducted group health education sessions about breastfeeding at the posyandu and in the villages. This is probably due to the low frequency of the health education sessions so that not all mothers can participate or receive information. In this study, however, the frequency of health education and participation of mothers was not further explored. Based on Government Regulation No. 33 of 2012, midwives must provide education sessions to pregnant women about the preparation of exclusive breastfeeding. In the education sessions, midwives are required to provide information related to breast care during pregnancy and train pregnant women to carry out breast care properly, however, the regulation does not mention how frequent the education sessions should be conducted. ${ }^{1}$

\section{The role of midwives in providing early breast feeding initiation to maternity women}

Interviews with midwives revealed that early breastfeeding initiation was always given. However, they also said that in certain circumstances early breastfeeding initiation cannot be carried out, such as in the case of postpartum bleeding and fetal distress. In those cases, lifesaving interventions are given in advance.

This study shows that all midwives already understood about early breastfeeding initiation, and stated they always conduct this when helping with labor. According to the informants, early breastfeeding initiation is very beneficial for the mother and infant because it improves mother and infant bonding, increase the infant's immune system and reduce the risk of bleeding and breast cancer among mothers. Based on the breastfeeding guidelines, early breastfeeding initiation immediately after the infant is born or at least the first hour is highly recommended. ${ }^{8,18}$

“... Emmm ... look at the situation. If normal delivery, her infant is born crying immediately, we encourage early breastfeeding initiation... If bleeding occurs, we focus on the bleeding.... Usually we do early breastfeeding initiation for about 1 hour" (IN 02_PHC midwife)

“... We immediately carry out early breastfeeding initiation. All immediately given. So when the infant is born, we immediately put it on the breast"(IN 05_private midwife)

"... The benefits of breastfeeding for mothers will be ... will accelerate the recovery of uterine, continue to prevent bleeding, to emmm....strengthen the relationship between mother and infant then to prevent breast cancer" (IN 04_private midwife)

Interviews with mothers show that most mothers did not receive early breastfeeding initiation and only one mother who was facilitated to have early breastfeeding initiation. Early breastfeeding initiation was not performed by midwives due to various factors such as bleeding during labor and infants do not cry immediately after birth. The statement of the mothers is in accordance with the statement of the midwife that early breastfeeding initiation 
cannot be conducted if the mother and infant experience medical indications such as bleeding or fetal distress. Based on the Republic of Indonesia Government Regulation No. 33/2012, every mother who gives birth must give exclusive breastfeeding to the infant. This provision does not apply if the mother has a medical indication or if the mother is separated from her infant. ${ }^{1}$

"... No, the problem is like this... (pause for a moment) emmm ... my child was born with the umbilical cord around his throat. So only after they cleaned him up did they give him to me" (IN 10_mother)

“... I only provide early breastfeeding initiation when the mother and baby are not in any kind of distress"(IN 04_midwife)

This study indicates that some situations may inhibit the early breastfeeding initiation such as bleeding during labor and fetal distress, so that early breastfeeding initiation cannot be conducted. Studies by Widiastuti ${ }^{19}$ and Mujiati ${ }^{20}$ found that there are many factors that can inhibit the provision of early breastfeeding initiation such as lack of maternal knowledge about the importance of early breastfeeding initiation, the condition of mothers and infants after delivery, lack of support from husbands and support of health workers in early breastfeeding initiation. Roesli's study on the implementation of early breastfeeding initiation shows that early breastfeeding initiation is not always a priority, for example in the condition when mothers experience bleeding or fetal distress. ${ }^{21}$

\section{The role of the midwife in maintaining exclusive breastfeeding during postpartum until the infant reaches six months old}

Interviews with midwives show that midwives had explained and trained mothers about breastfeeding proper positions and techniques. However, the mothers explained that the midwives had never demonstrated the correct breastfeeding position and technique. Mothers who were successful in providing exclusive breastfeeding stated that they learned breastfeeding positions and techniques on their own to suit their comfort or were assisted by the family. One mother stated that she had never been trained in breastfeeding positions and techniques because the infant had to be treated in an incubator.

"... we teach breastfeeding techniques, how to breastfeed correctly, we immediately teach. Including nipple and breast care."(IN 03_PHC midwives)

"...We figured out everything by ourselves" (IN 11_mother)
This study shows that there is a different information gained from midwives and mothers, where midwives stated that they have trained mothers in the correct breastfeeding position and techniques, whereas mothers of children under five have stated that they have never been trained by midwives. No study has been published on the role of midwives in training mothers in breastfeeding positions and techniques. A study in Bantul, Yogyakarta shows that breastfeeding counselling for mothers can increase maternal motivation in providing exclusive breastfeeding. ${ }^{22}$

Interviews with mothers and midwives indicate that midwives have provided information and counselling about breastfeeding to working mothers and is usually done when the mother visits the PHC. The midwives also said that they had trained mothers on how to express milk properly, to store breast milk in a bottle, to put milk in the refrigerator and how to present milk. On the other hand, a working mother said that she had never received any information or counselling from the midwife regarding this issue.

"... For most of the mothers who work, we teach the method of breastfeeding... when they come to the PHC” (IN 03_PHC midwife)

"... We explain to them how to express milk, how to correctly store it. We have explained it like that. "(IN 05_private midwife)

“... Yes, I work, and they definitely didn't explain anything to me (laugh)" (IN 08_mother)

This study shows that there is a difference in information obtained from midwives and mothers who work. The midwives stated that they had provided counselling about breast milk for working mothers, while a working mother said that she had never received information about breast milk. This is likely because not all midwives provide explanations or counselling about breastfeeding to working mothers, but this study does not explore further about this. Based on the Ministry of Health \& JICA Guidelines, midwives are required to provide information and train mothers who work on breastfeeding. ${ }^{8}$ This guideline is supported by Government Regulation No.33 of 2012 which states that midwives are required to provide information and education on exclusive breastfeeding to the mother or family member of the infant from the time of the pregnancy examination until the exclusive breastfeeding period is complete. The information and education are in the form of counselling, counselling and assistance. ${ }^{1}$ Studies on information provision regarding expressed milk for working mothers remain very limited and no study has explored the role of 
midwives in providing this information. A study in Yogyakarta showed that there was an association between good maternal knowledge on how to store breast milk with exclusive breastfeeding to infants. ${ }^{23}$

Interviews with midwives showed that midwives counselled and trained mothers in breast care in an effort to overcome problems during breastfeeding. Counselling is given in the form of how to overcome the problem of nipple or how to prevent/ address mastitis. While mothers, both who give exclusive breastfeeding and who do not, say they have never been assisted by a midwife in breast care to overcome problems such as blisters.

“... We provide IEC on how to care for nipples and breasts during breastfeeding." (IN 05_PHC midwife)

"... I have never been helped by the midwife, if I blister, I will let it heal later, sometimes I will add honey too." (IN 09_mother)

In this study, there was a difference in information between midwives and mothers regarding the role of midwives in overcoming breastfeeding problems during the postpartum period. It is likely that not all midwives have provided counselling and trained mothers in breast care to overcome breastfeeding problems. The Ministry of Health \& JICA Guidelines state that during the postpartum period midwives are required to conduct breast examinations and provide counselling regarding exclusive breastfeeding. ${ }^{8}$ Other studies have not explored the role of midwives in overcoming breastfeeding problems during the postpartum period. Other studies have only described the experience and psychosocial support that mothers receive from families when facing breastfeeding problems during the postpartum period. ${ }^{24}$

Interviews with midwives showed that home visits during the postpartum period were not carried out for all mothers. Home visits are conducted only for mothers who have a history of high-risk pregnancy. Most mothers come to health providers for control or immunization. Interviews with mothers also indicate that midwives never make home visits after delivery. Mother stated that they came to the health services during the child's immunization schedule.

"... There are home visits, but mostly the mothers who come to the health services. Distance to conduct home visits is an obstacle but we try when a patient has had a difficult birth... "(IN 05_private midwife)

"... The midwife has never been here. Most of us go there when I get immunization." (IN 12_mother)
The study found that midwives did not make home visits to all mothers during the postpartum period. This is not in accordance with midwifery care guidelines for normal postpartum mothers which states that midwives should make postpartum visits four times, 6-8 hours after delivery, 6 days, 2 weeks and 6 weeks post-delivery in order to assess the condition of mothers and new borns and preventing, detecting and managing complications during the postpartum period including assessment of breastfeeding. ${ }^{9}$ Studies on postpartum visits remain very limited. A study in Blora Semarang found that most midwives had low motivation to carry out postpartum services. ${ }^{25}$ The results of a systematic review show that home visits during the postpartum period can increase maternal motivation to provide exclusive breastfeeding. ${ }^{26}$

Interviews with nutrition program manager and midwives revealed that there were several barriers to carry out home visits during the postpartum period, namely the lack number and the high workload of health workers, the dense population, distance to the mothers' houses and unclear data on mothers' addresses. One of the efforts made to overcome these obstacles is to involve posyandu cadres in home visits, although home visits cannot always be done.

“... For home visits, the inhibiting factor ... (pause for a moment) maybe the health workers. Because there is a lack of human resources in PHC in the sense of emmm ... each program manager holds more than one program. Well, in one program there are also many indicators, and we also have a lot of integration. Maybe because we are in a heterogeneous area with a large population. That's the obstacle there. So emmmm, it's impossible for us to visit all ... But what is clear is that we monitored exclusive breastfeeding at posyandu. If she does not come to the posyandu, the cadre will go to their houses for a home visit." (IN 06_nutrition program manager)

The results of this study are similar to the study in Semarang which shows that midwives' perceptions and knowledge influence the implementation of home visits. ${ }^{25}$ In the study midwives stated that conducting home visits is a heavy burden and midwives' ignorance of postpartum management leads to midwives' less motivation to make a visit during the postpartum period. While a study in Kenya, Africa shows that the low post natal care services are influenced by several factors such as, education and skills of health workers which remain lacking. ${ }^{27}$ 
The limitation of this study is that some conflicting responses between mothers and midwives were not explored well during the data collection in order to understand why the differences occurred. There is a possibility of different perception between mothers and midwives regarding some terms used during the interviews. Finally, there is a possibility of recall bias as all informants have children with the youngest age of 18 months or more.

\section{CONCLUSION}

The role of the midwife in facilitating exclusive breastfeeding during pregnancy, childbirth and the postpartum period is still superficial and does not comply with midwifery care guidelines. The role of midwives needs to be enhanced to increase exclusive breastfeeding.

\section{ACKNOWLEDGEMENTS}

We would like to express gratitude to the Head of Kuta I PHC who have facilitated the study implementation and to midwives in the area of Kuta I PHC who have participated in this study.

\section{REFERENCES}

1. Indonesia Ministry of Health. Peraturan Pemerintah Republik Indonesia Nomor 33 Tahun 2012 Tentang Pemberian Air Susu Ibu Eksklusif [The Government of the Republic of Indonesia Act No. 33 Year 2012 on Exclusive Breastfeeding]. Jakarta: Indonesia Ministry of Health; 2012.

2. Setiawati E, Mukhtar, Maslani N. 2014. Hubungan sikap dan peran bidan terhadap program pemberian ASI ekslusif di wilayah kerja Puskesmas Jambu Burung Kabupaten Banjar [The association between attitude and roles of midwives with exclusive breastfeeding at the area of Jambu Burung Public Health Center, Banjar District]. Jurnal Skala Kesehatan. 2015;6(1).

3. Retnani DA. Hubungan peran petugas kesehatan dengan motivasi ibu dalam pemberian ASI eksklusif di Desa Wonorejo Kecamatan Kencong Kabupaten Jember (Tesis) [Association between the roles of health workers and mothers' motivation in the provision of exclusive breastfeeding in Wonorejo Village, Kencong Sub-district, Jember District (Thesis)]. Jember: The University of Jember; 2016

4. Prayogo D. Hubungan peran bidan dan dukungan suami dengan pemberian ASI eksklusif di wilayah kerja Puskesmas Colomadu I (Skripsi) [Association between the roles of midwives and husband's support with exclusive breastfeeding at the area of Colomadu I Public Health Center (Undergraduate thesis)]. Surakarta: Muhammadiyah University; 2013

5. Pratiwi EHN, Tarmaly A, Rosalina. Hubungan peran bidan dengan perilaku pemberian ASI eksklusif pada ibu yang memiliki bayi usia 0-6 bulan di Kelurahan Bawen Kecamatan Bawen Kabupaten Semarang (Skripsi) [Association between the roles of midwives and exclusive breastfeeding among mothers who have babies aged 0-6 months in Bawen Village, Bawen Sub-district, Semarang District (Undergraduate thesis)]. Semarang: Ngudi Waluyo Health Institute; 2015.
6. Raharjo BB. Profil ibu dan peran bidan dalam praktik inisiasi menyusu dini dan ASI eksklusif [Mother's profile and the roles of midwives in the early breastfeeding initiation and exclusive breastfeeding]. Jurnal Kesehatan Masyarakat. 2014; 10(1): 53-63.

7. Bali Province Health Office. Profil Kesehatan Provinsi Bali Tahun 2015 [The 2015 Bali Province Health Profile]. Denpasar: Bali Province Health Office; 2016.

8. Indonesia Ministry of Health, Japan International Cooperation Agency. Buku Kesehatan Ibu dan Anak [Mother and Child Health Book]. Second Edition. Jakarta: Indonesia Ministry of Health; 2016.

9. Fitriani N. Peran bidan terhadap keberhasilan pemberian ASI ekslusif di Puskesmas Sruwohrejo, Kecamatan Butuh, Kabupaten Purworejo [The roles of midwives in the success of exclusive breastfeeding at Sruwohrejo Public Health Center, Butuh Sub-district, Purworejo District]. Yogyakarta: Jenderal Achmad Yani Health Institute; 2015.

10. Titrawati NWD. Peran bidan praktik swasta dalam pemberian ASI eksklusif di wilayah kerja Puskesmas Abiansemal Kabupaten Badung tahun 2017 (Skripsi) [The roles of private midwives in exclusive breastfeeding at the area of Abiansemal Public Health Center, Badung District, year 2017(Undergraduate thesis)]. Denpasar: Universitas Udayana; 2017.

11. Badung District Health Office. Profil Kesehatan Kabupaten Badung Tahun 2017 [The 2017 Badung District Health Profile]. Badung: Badung District Health Office; 2018.

12. Switaningtyas W, Hariyanto T, Adi RCW. Hubungan perawatan payudara antenatal dengan percepatan sekresi kolostrum pada ibu post-partum di RSIA MW Malang [Association between antenatal breast care and acceleration of colostrum secretion among post-partum mothers at MW Mother and Child Hospital]. Nursing News. 2017; 2(3): 134-143.

13. Najat. Perawatan payudara sebagai intervensi dalam mengatasi masalah ketidakefektifan pemberian ASI pada keluarga Bapak RM, Kelurahan Sukatani (Skripsi) [Breast care as an intervention in managing breastfeeding ineffectiveness in Mr. RM family, Sukatani Village (Undergraduate thesis)]. Depok: Universitas Indonesia; 2014.

14. Sari DP. Asuhan keperawatan dengan penerapan breastcare untuk meningkatkan produksi ASI pada pasien post SC di Ruang Bougenvil RSUD Dr. Soedirman Kebumen (Skripsi) [Nursing care by implementing breastcare to increase breastmilk production among post SC patients in Bougenvil Room Dr. Soedirman Hospital (Undergraduate thesis)]. Kebumen: Muhammadiyah Health Institute. 2017.

15. Alhadar F, Umaternate I. Pengaruh perawatan payudara pada ibu hamil terhadap peningkatan produksi ASI di wilayah kerja Puskesmas Kota Kecamatan Kota Ternate Tengah tahun 2016 [The effect of breast care among pregnant mothers on the increase of breastmilk production at the area of Kota Kecamatan Public Health Center, Middle Ternate City year 2016]. Jurnal Riset Kesehatan. 2017; 6(1): 7-12.

16. Pricilla RA, David KV, Siva R, Vimala TJ, Rahman SP, Angeline N. 2017. Quality of Antenatal Care Provided by Nurse Midwives in an Urban Health Centre with Regard to Low-Risk Antenatal Mothers. Indian Journal of Community Medicine. 2017;42(1):37-42.

17. Grimes HA, Forster DA, Newton MS. Sources of information used by women during pregnancy to meet their information needs. Midwifery. 2014;30(1):26-33.

18. Mufdlilah, Subijanto AA, Sutisna E, Akhyar M. Buku Pedoman: Pemberdayaan ibu menyusui pada program ASI eksklusif [Guidelines book: Empowering mothers in the exclusive breastfeeding program]. Yogyakarta; 2017.

19. Widiastuti YP, Rejeki S, Khamidah N. 2013. Faktorfaktor yang mempengaruhi pelaksanaan inisiasi menyusu dini di Ruang Mawar, Rumah Sakit Umum Daerah Dr. H. Soewondo, Kendal [Factors influencing the early breastfeeding initiation in Mawar Room, Dr. H. Soewondo Hospital, Kendal]. Jurnal Keperawatan Maternitas. 2013;1(2): 142-146. 
20. Novianti, Mujiati. 2015. Faktor pendukung keberhasilan praktik inisiasi menyusu dini di RS swasta dan rumah sakit pemerintah di Jakarta [Enablers of early breastfeeding initiation at the private and public hospitals in Jakarta]. Jurnal Kesehatan Reproduksi. 2015;6(1):31-44.

21. Roesli U. Inisiasi menyusu dini plus ASI eksklusif [Early breastfeeding initiation plus exclusive breastfeeding]. Jakarta: Pustaka Bunda; 2008.

22. Faizah U. Pengaruh konseling teknik menyusui yang benar pada ibu postpartum terhadap motivasi ibu dalam pemberian ASI di RSU PKU Muhammadiyah, Bantul (Skripsi) [The effect of breastfeeding technique counseling among postpartum mothers on mother's motivation in breastfeeding at Muhammadiyah Hospital, Bantul (Undergraduate thesis)]. Yogyakarta: Aisyiyah Health Institute; 2014.

23. Nuryanti WD. Hubungan tingkat pengetahuan tentang penyimpanan ASI dengan pemberian ASI eksklusif pada ibu bekerja di wilayah kerja Puskesmas Bantul II, Yogyakarta (Skripsi) [The association between knowledge on breastmilk storage with exclusive breastfeeding among working mothers at the area of Bantul II Public Health Center, Yogyakarta (Undergraduate thesis)]. Yogyakarta: Aisyiyah Health Institute; 2014.
24. Jeniawaty S, Utami S, Mairo QKN. Asuhan keperawatan psikososial pada ibu postpartum dalam menghadapi ASI belum keluar pada 0-3 hari pascasalin [Psychosocial nursing care among postpartum mothers for managing breastfeeding problems in the day $0-3^{\text {rd }}$ after delivery]. Jurnal Ners. 2016;11(2):261-268.

25. Saptaningrum E, Jati SP, Suparwati A. Faktor-faktor yang mempengaruhi motivasi bidan pelaksana dalam pelayanan ibu postpartum di wilayah Kabupaten Blora [Factors influencing the motivation of midwives in postpartum care for mothers at Blora District]. Jurnal Manajemen Kesehatan Indonesia. 2016;4(2):139-147.

26. Yonemoto N, Dowswell T, Nagai S, Mori R. Schedules for home visits in the early postpartum period. The Cochrane Database of Systematic Reviews. 2013;23(7):1-71.

27. Akunga D, Menya D, Kabue M. Determinants of postnatal care use in Kenya Daniel. African Population Studies. 2014;28(3):1447-1459.

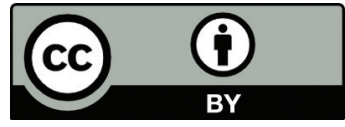

This work is licensed under a Creative Commons Attribution 